\title{
Multiple lesions of granuloma annulare on the hand in a patient with scabies
}

This article was published in the following Dove Press journal:

Clinical, Cosmetic and Investigational Dermatology

22 August 2011

Number of times this article has been viewed

\author{
Khalid Al Aboud' \\ Daifullah Al Aboud ${ }^{2}$ \\ 'Department of Dermatology, \\ King Faisal Hospital, Makkah; \\ ${ }^{2}$ Department of Dermatology, \\ Taif University, Taif, Kingdom \\ of Saudi Arabia
}

\begin{abstract}
Granuloma annulare induced by scabies infection has been described previously in three patients. In this report, we share our observation of a fourth case.

Keywords: granuloma annulare, scabies, skin

\section{Introduction}

Granuloma annulare (GA) is a common chronic dermatosis of unknown etiology. It is characterized by small papules that are often fused into annular arrangements. ${ }^{1-3}$ Several variants are known, ie, localized GA, generalized GA, subcutaneous GA, perforating GA, and arcuate dermal erythema. Localized GA is the most common of the subtypes. However, in patient with human immunodeficiency viral infection, generalized GA is the most frequent clinical pattern. ${ }^{3} \mathrm{GA}$ is more common in women and children, and young adults are predominantly affected. ${ }^{2}$

Scabies is a contagious infestation of the skin by Sarcoptes scabiei, a mite which lives in the stratum corneum of the human host. It is characterized by an intensely pruritic papular eruption. ${ }^{3}$ Like syphilis, scabies has come to be known as a "great imitator". ${ }^{2}$ GA induced by scabies infection has been described previously in three cases. Here we report a fourth case.
\end{abstract}

\section{Case report}

A 29-year-old woman presented with severe pruritus of 1 month in duration. The patient was not known to have any systemic disease. On examination, the patient had generalized excoriation with skin burrows. Scraping for scabies was positive. In addition, the patient had multiple erythematous nonscaly plaques localized on the dorsum of the right hand. According to the patient, these lesions appeared for the first time with the pruritus. Skin biopsy from one of the annular plaques revealed palisaded granulomas containing mucin and degenerated collagen, confirming the diagnosis of GA. The patient was treated successfully for scabies by three nights of application of benzyl benzoate $25 \%$, and is currently being treated with topical steroids for GA, with good improvement.

\section{Discussion}

GA is a benign, inflammatory skin disease of unknown etiology. There are several theories concerning the pathogenesis of GA, including cellular immune defects, metabolic disorders, and a primary disease of altered collagen and/or elastin. ${ }^{2}$ 
Table I Summary of reported cases of granuloma annulare precipitated by scabies

\begin{tabular}{|c|c|c|c|}
\hline Reference & Patient age (years) & Gender & Comments \\
\hline Vignale et al' & 52 & $M$ & $\begin{array}{l}\text { One month after being treated for scabies, the patient } \\
\text { develops generalized GA. }\end{array}$ \\
\hline Wilsmann-Theis et $\mathrm{al}^{2}$ & 50 & $\mathrm{~F}$ & $\begin{array}{l}\text { Patient had a I0-year history of relapsing GA, on the trunk, } \\
\text { limbs, thighs, and knees which become resistant to topical } \\
\text { treatment after infection with scabies. }\end{array}$ \\
\hline Piana et $\mathrm{al}^{3}$ & 50 & $M$ & $\begin{array}{l}\text { Two months after being treated for scabies, the patient } \\
\text { developed GA in the form of a diffuse erythematopapular } \\
\text { eruption, mainly located on the trunk and on upper limbs. } \\
\text { The lesions were flesh-colored or red and were widespread, } \\
\text { without evident annular configuration. }\end{array}$ \\
\hline Present case & 27 & $\mathrm{~F}$ & $\begin{array}{l}\text { Generalized pruritus with multiple annulare plaques } \\
\text { on the right hand. }\end{array}$ \\
\hline
\end{tabular}

Abbreviations: $M$, male; F, female; GA, granuloma annulare.

Diabetes mellitus, thyroid disease, human immunodeficiency viral infection, and hepatitis $\mathrm{C}$ infection appear to be predisposing factors. ${ }^{2}$ Explained by an isomorphic phenomenon (Koebner reaction), GA as well as scabies can trigger other diseases. GA may appear following, and sometimes at the same site, of other diseases. These diseases include mycobacterial and fungal infections, herpes simplex infection, herpes zoster, erythema multiforme minor, insect bites, vaccines, and both Hodgkin's and non-Hodgkin's lymphoma. ${ }^{3}$

Scabies infection is known to hide behind and to trigger other diseases ${ }^{2,3}$ such as urticaria, lichen ruber, psoriasis, dermatitis herpetiformis, Darier's disease, Hailey-Hailey disease, Grover disease, and bullous pemphigoid. Patients with scabies have been found to have high levels of immunoglobulin E, immunoglobulin G, and eosinophils. ${ }^{4}$ These immunological changes may act as a trigger for immune dysregulation and favor development of GA. ${ }^{3}$

Table 1 summarizes the reported cases of GA precipitated by scabies infection.

From this table, it can be seen that scabies was followed by generalized (first and third cases) and localized (present case) GA, whereas in the second case scabies was observed in a patient with a 10-year history of GA. We agree with others who have speculated that the occurrence of GA with scabies might not be rare but simply overlooked. ${ }^{2}$ Scabies should be added to the list of possible trigger factors for exacerbation and atypical presentations of GA.

\section{Disclosure}

The authors report no conflicts of interest in this work.

\section{References}

1. Vignale RA, Casella de Vilaboa E, Paciel J, Bruno J. Disseminated annular granuloma in a patient with scabies. Med Cutan Ibero Lat Am. 1990;18(4):252-256. Spanish.

2. Wilsmann-Theis D, Wenzel J, Gerdsen R, Uerlich M, Bieber T, Granuloma annulare induced by scabies. Acta Derm Venereol. 2003; 83(4):318.

3. Piana S, Pizzigoni S, Tagliavini E, Serra S, Albertini G. Generalized granuloma annulare associated with scabies. Am J Dermatopathol. 2010;32(5):518-520.

4. Arlian LG, Morgan MS, Estes SA, Walton SF, Kemp DJ, Currie BJ. Circulating IgE in patients with ordinary and crusted scabies. $J$ Med Entomol. 2004;41(1):74-77.
Clinical, Cosmetic and Investigational Dermatology

\section{Publish your work in this journal}

Clinical, Cosmetic and Investigational Dermatology is an international, peer-reviewed, open access, online journal that focuses on the latest clinical and experimental research in all aspects of skin disease and cosmetic interventions. All areas of dermatology will be covered; contributions will be welcomed from all clinicians and

\section{Dovepress}

basic science researchers globally. This journal is indexed on CAS The manuscript management system is completely online and includes a very quick and fair peer-review system, which is all easy to use. Visit http://www.dovepress.com/testimonials.php to read real quotes from published authors. 